\title{
Trade Openness and Democracy: The Case of Gabon
}

\author{
Assoumou Ondo \\ CIREGED, Omar Bongo University, Libreville, Gabon \\ Email: assoumou7ondo@gmail.com
}

How to cite this paper: Ondo, A. (2017) Trade Openness and Democracy: The Case of Gabon. Modern Economy, 8, 191-198. https://doi.org/10.4236/me.2017.82013

Received: December 22, 2016

Accepted: February 6, 2017

Published: February 9, 2017

Copyright (C) 2017 by author and Scientific Research Publishing Inc. This work is licensed under the Creative Commons Attribution International License (CC BY 4.0).

http://creativecommons.org/licenses/by/4.0/

\begin{abstract}
This article analyzes the relation between trade openness and democracy in Gabon. Unlike traditional approaches based on the estimation of linear gravity models, we first estimate a nonlinear model characterizing the relation between democracy and trade openness. We then determine an optimal threshold beyond which democracy has a positive effect on trade openness in Gabon.
\end{abstract}

\section{Keywords \\ Trade Openness, Democracy, Nonlinear Relation}

\section{Introduction}

Under the structural adjustment programs of the International Monetary Fund, there is renewed interest in the analysis of the relation between trade openness and democracy in developing countries, where there may be conflicts between them two objectives [1].

Indeed, democracy offers the possibility for lobbies and pressure groups to influence the decisions of the state (central government and bureaucrats). In this respect, it may help to reduce the degree of trade openness [2]. This hypothesis of the effect of democracy on trade openness has been the basis of an important theoretical and empirical literature.

On the theoretical level, the literature reveals two (2) main points of view. The first refers to the work of Mansfield, Milner and Rosendorff (2000) [3], Kubota and Milner (2005) [4] and $\mathrm{Yu}$ (2010) [5] who postulate a positive relation between trade openness and democracy through economic freedom and the quality of governance. The second point of view, defended by Granger and Siroën (2001) [6], Eichengreen and Le Blang (2008) [7], Duc, Granger and Siroën (2008) [8] is part of the economy of trade policy. It identifies a convex relation between trade openness and democracy, due to the relative influences of pres- 
sure groups, protectionist or liberal lobbies. In fact, unlike an autocratic system, a representative or direct democracy increases the influence exerted by different interest groups. Thus, Mayer (1984) shows in particular that in direct democra$\mathrm{cy}$, the policy of commercial openness is determined in such a way as to satisfy the individual interests of the median voter. On the other hand, Findlay and Wellisz (1982) [9] and Mitra (1999) [10] show, in a representative democracy, that trade policy would be influenced by liberal and/or protectionist lobby groups and political parties.

On the empirical level, several studies attempt to characterize the relationship between democracy and trade openness from two (2) methods. The first estimates a decline in the openness of a country on indicators of democracy [11]. The second method uses the estimation of gravity models [6]. Thus, in the case of developed countries, Hamilton (2002) uses a "Freedom House" indicator to measure the level of democracy and two alternative indicators of economic openness: the simple tariff average and the share of Trade in GDP [12]. He observes a positive and significant correlation between the two measures of openness and democracy. Similarly, Duc, Granger and Siroën (2007), in the case of the countries of the North and the South, propose an estimate in panel data. The results show that democracy increases openness in South-South trade. On the other hand, the opposite effect occurs when it involves a northern country. Milner and Kubota (2005) observe that democracy favors open trade. In particular, they show that democracy contributes to reducing barriers to trade in a number of developing countries. Finally, Balding (2011) examines the relation between democracy and trade openness in developing countries. According to the author, democracy is likely to have a positive effect on trade openness in countries where good governance is proven.

In Africa, it seems that the study of the relation between trade openness and democracy has not attracted much interest until a recent past. This is particularly the case in Gabon, a small country open to the outside and dependent on oil, which is experiencing an acute economic and financial crisis since the drop in prices of this raw material. On the other hand, the future direction of its trade relations with the European Union countries, the Economic Partnership Agreements and the political challenges arising from the last presidential elections, suggest that the country must implement both Economic and political reforms.

This paper refers to Gabon, it's a contribution to the study of the relations between trade openness and democracy in sub-Saharan Africa (SSA) in that it uses a non-linear model to determine an optimal threshold of democracy. The rest of the study is organized as follows: Section 2 presents the model for determining the optimal threshold for democracy. Section 3 is devoted to empirical analysis. Finally, Section 4 concludes.

\section{The Model of Determination of the Optimal Threshold of Democracy}

\subsection{Presentation of the Model}

Like Niyongabo (2008) [13], we rely on a general equation of determination of 
trade openness by a set of economic and geographical explanatory variables.

Trade openness (tope $_{\mathrm{t}}$ ) is the explanatory variable of the model. It is defined by the sum of exports and imports expressed as a percentage of GDP [6] [13].

Thus, the equation for determining the degree of trade openness is:

$$
\text { ouv }_{\mathrm{t}}=\alpha+\beta \mathrm{X}_{\mathrm{t}}+\varepsilon_{\mathrm{t}}
$$

where:

- ouv $_{\mathrm{t}}$ is the ratio of exports and imports to GDP in\%;

$-\mathrm{X}_{\mathrm{t}}$ includes all economic and geographic variables;

$-\alpha$, a constant;

$-\mathcal{E}_{\mathrm{t}}$, an error term.

Like Granger and Siroën (2001), we increase the equation (1) of institutional variables (democracy, in particular) to nonlinear effects.

Our equation [1] can thus be written as follows:

$$
\operatorname{ouv}_{\mathrm{t}}=\alpha+\mathrm{a}_{1} \mathrm{demo}_{\mathrm{t}}+\mathrm{a}_{2} \mathrm{demo}_{\mathrm{t}}^{2}+\beta \mathrm{X}_{\mathrm{t}}+\varepsilon_{\mathrm{t}}
$$

where:

- ouv $_{\mathrm{t}}$ is the ratio of exports and imports to GDP in \%;

- demo $_{\mathfrak{t}}$, is the level of democracy, measured by an index of democracy created in 2006 by "The Economist Group";

$-\mathrm{X}_{\mathrm{t}}$, includes all economic and geographic variables;

$-\alpha$, a constant;

$-\mathcal{E}_{\mathrm{t}}$, an error term.

We retain a priori five economic and geographic variables $\mathrm{X}_{\mathrm{t}}$. The first factor is the population level $\left(\mathrm{pop}_{\mathrm{t}}\right)$ which has a negative theoretical sign: the larger the size of the economy, the more it is self-sufficient or the less it exchanges with the rest of the world. The second explanatory variable is the level of GDP $\left(\mathrm{gdp}_{\mathrm{t}}\right)$ which has a positive effect on the degree of trade openness. The more a rich/ developed economy, the more it trades with the outside in relative terms. The level of development would diminish the effect of distance between markets, both by relative cost mechanisms and by an increased circulation of information [6]. This positive effect on openness is also expected for the third variable, the GDP of the country's main trading partner $\left(\operatorname{dgpf}_{t}\right)$. Price levels $\left(\mathrm{ipc}_{\mathrm{t}}\right)$ and investment $\left(\right.$ inv $\left._{t}\right)$ represent the fourth and fifth explanatory variables of trade openness. The level of domestic prices appears to have an effect on the degree of trade openness in different ways [14]. First, the level of prices directly affects the level of GDP. Two (2) countries which are identical in external trade but with different domestic price systems will have distinct degrees of openness. A high price level in the non-tradable sector contributes to reducing the degree of openness of an economy by increasing the denominator of this ratio. Second, the level of domestic prices influences foreign trade through substitution and/or competitiveness effects which are opposite in direction to imports and exports. A low price level tends to reduce import demand but can jointly have a positive impact on exports. As levels of exports and imports are also linked by the external equilibrium constraint, we can see how complex the relation between prices 
and openness [14]. As regards investment, it makes it possible to specify the international specialization of the country and justifies additional gains at the opening, in addition to foreign direct investment [15].

The relation between trade openness and democracy is finally determined from the equation below:

$$
\begin{aligned}
\operatorname{louv}_{\mathrm{t}}= & \mathrm{a}_{0}+\mathrm{a}_{1} \operatorname{demo}_{\mathrm{t}}+\mathrm{a}_{2} \operatorname{demo}_{\mathrm{t}}^{2}+\mathrm{a}_{3} \operatorname{lpop}_{\mathrm{t}}+\mathrm{a}_{4} \operatorname{ldgp}_{\mathrm{t}} \\
& +\mathrm{a}_{5} \operatorname{lgdpf}_{\mathrm{t}}+\mathrm{a}_{6} \operatorname{lipc}_{\mathrm{t}}+\mathrm{a}_{7} \operatorname{linv}_{\mathrm{t}}+\varepsilon_{\mathrm{t}}
\end{aligned}
$$

where:

-louv , commercial opening;

- demo $_{t}$, democracy;

-lpop ${ }_{t}$, the population;

$-\operatorname{lgd} p_{\mathrm{t}}$, the gross domestic product;

- $\operatorname{lgdpf} \mathrm{f}_{\mathrm{t}}$, the gross domestic product of major trading partner;

-lipc $c_{t}$, the price level;

$-\operatorname{linv}_{t}$, the level of domestic investment;

$-\mathcal{E}_{\mathrm{t}}$, an error term.

\subsection{Optimization of the Model}

We optimize equation (3) to determine the optimal threshold of democracy $\left(\right.$ demo $\left._{t}^{*}\right)$. The determination of the candidate point results from the first order conditions (CPO) and those of second order (CSO):

The first order conditions give the following equation:

$$
\frac{\partial \text { louv }_{t}}{\partial \text { demo }_{t}}=0
$$

The resolution of equation (4) results in the following formula:

$$
\mathrm{a}_{1}+2 \mathrm{a}_{2} \mathrm{demo}_{\mathrm{t}}^{*}=0
$$

where:

- demo* , the optimal threshold for democracy;

$-a_{1}$, the effect of democracy on trade openness;

$-a_{2}$, the effect of the square of democracy on trade openness.

The second order conditions (CSO) show that if $a_{2}$ is negative and $a_{1}$ is positive, then the function $\mathrm{f}$ is concave and the optimal threshold $\left(\right.$ demo $\left._{t}^{*}\right)$ corresponds to a maximum. On the other hand, if $a_{2}$ has a positive sign and $a_{1}$ is negative, then the function $f$ is convex and the optimal threshold $\left(\right.$ demo $\left._{t}^{*}\right)$ corresponds to a minimum.

\section{Empirical Analysis}

On the first part we present the methodology; we will proceed on the second part to interpret the results.

\subsection{Methodology}

The data used to enter the variables comes from the World Bank database, with 
the exception of the Democracy Index, which comes from the annual reports of the economist intelligence unit. The variables have been transformed into logarithms apart from the democracy index, i.e. $\operatorname{louv}_{\mathrm{t}}, \operatorname{lpop}_{\mathrm{t}}, \operatorname{lpib}_{\mathrm{t}}$, $\operatorname{lpibf}_{\mathrm{t}}, \operatorname{lipc}_{\mathrm{t}}$ et $\operatorname{linv}_{\mathrm{t}}$. Moreover, the GDP of Gabon's main trading partner $\left(\mathrm{pibf}_{\mathrm{t}}\right.$ ) corresponds to that of France. It remains Gabon's leading supplier, with 21\% market share (2014).

We use historical data to estimate the relationship between democracy and trade openness over the period 2006-2015. In order to broaden the sample size, we proceed with the quarterly data.

The nonlinear model of polynomial form (3) is estimated using the nonlinear least squares method (or NLS). This method has two steps:

The first one consists in verifying that the series lend themselves to a nonlinear estimation based on the analysis of descriptive statistics (Kurtosis and Skewness tests, followed by a graphical analysis). If the elements of descriptive statistics confirm the presence of asymmetries, then it becomes possible to estimate the parameters of the model by the least squares nonlinear (or NLS). The second relates to the estimation of the polynomial by the nonlinear least squares method in order to integrate the nonlinearity of the effects of democracy on the degree of trade openness due to the imperfect competition context characterizing international trade. The model thus estimated is globally validated by the correlation coefficient $\left(\mathrm{R}^{2}\right)$.

\subsection{Interpretation of Results}

Table 1 presents the results of the preliminary tests of normality and asymmetry of the various variables.

Table 1 shows that the hypothesis of symmetry is rejected for all variables except democracy $\left(\right.$ demo $\left._{t}\right)$ and investment $\left(\right.$ linv $\left._{t}\right)$. Skweness statistics are significant at the critical 5\% threshold for trade openness $\left(\operatorname{louv}_{t}\right)$, Gabon's GDP $\left(\operatorname{lgdp}_{t}\right)$, France's GDP $\left(\operatorname{lgdpf}_{\mathrm{t}}\right)$, price level $\left(\operatorname{lipc}_{\mathrm{t}}\right)$ and population $\left(\operatorname{lpop}_{\mathrm{t}}\right)$. Consequently, these variables are a priori asymmetric, and can be assimilated to a non-linearity.

Table 1. Flattening and asymmetry statistics.

\begin{tabular}{ccc}
\hline Variables & Pr(Skewness) & $\operatorname{Pr}$ (Kurtosis) \\
\hline $\operatorname{louv}_{\mathrm{t}}$ & $0.0000^{*}$ & $0.0000^{*}$ \\
$\operatorname{demo}_{\mathrm{t}}$ & 0.7972 & 0.3204 \\
$\operatorname{lgdp}_{\mathrm{t}}$ & $0.0000^{*}$ & $0.0001^{*}$ \\
$\operatorname{lgdpf}_{\mathrm{t}}$ & $0.0000^{*}$ & $0.0000^{*}$ \\
$\operatorname{lpop}_{\mathrm{t}}$ & $0.0000^{*}$ & $0.0001^{*}$ \\
$\operatorname{lipc}_{\mathrm{t}}$ & $0.0000^{*}$ & $0.0000^{*}$ \\
$\operatorname{linv}_{\mathrm{t}}$ & 0.3150 & $0.0000^{*}$
\end{tabular}

a. $\left(^{*}\right)$ the coefficients are significant at the $1 \%$; $\left(^{* *}\right)$ the coefficients are significant at the $5 \%$; $\left({ }^{* *}\right)$ the coefficients are significant at the $10 \%$. 
In addition to the asymmetric nature of certain variables, non-linearity is also highlighted in the relationship between trade openness and democracy, as shown in Figure 1 below.

The demonstration of the nonlinearity of the relationship between commercial openness and democracy leads us to estimate the model by the nonlinear least squares method. The results of this estimate can be seen in the following Table 2.

The estimation of the model reveals the existence of a convex relationship between democracy and the degree of commercial openness in Gabon, which reinforces the results of Granger and Siroën (2001) and contradicts the work of Milner and Kubota (2005) and Yu (2010) that only countries with high levels of democracy, generally the major industrialized countries, have higher rates of openness.

On the other hand, the gross domestic product $\left(\operatorname{lgdp}_{\mathrm{t}}\right)$ and the population $\left(\right.$ lpop $\left._{\mathrm{t}}\right)$ have negative $(-0.707$ and -2.303$)$ and significant (respectively at the $10 \%$ and $1 \%$ thresholds) Commercial opening $\left(\right.$ ltope $_{\mathrm{t}}$ ). This result confirms

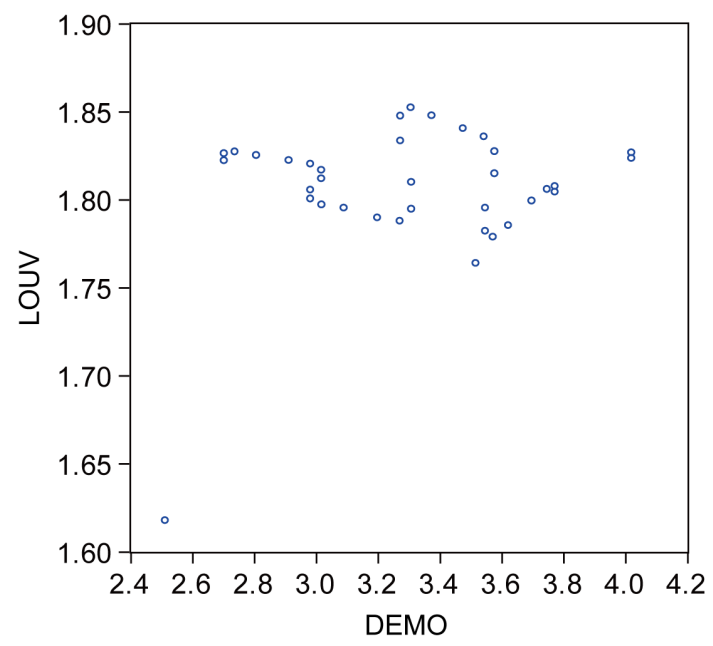

Figure 1. Relationship between trade openness and democracy.

Table 2. Estimated results.

\begin{tabular}{cc}
\hline louv $_{\mathrm{t}}$ & Coef \\
\hline $\operatorname{demo}_{\mathrm{t}}$ & $-0.542^{\star}$ \\
$\operatorname{demo}_{\mathrm{t}}^{2}$ & $0.059^{* * *}$ \\
$\operatorname{lgdp} \mathrm{t}$ & $-0.707^{* * *}$ \\
$\operatorname{lgdpf}$ & $2.545^{\star}$ \\
$\operatorname{lpop}_{\mathrm{t}}$ & $-2.303^{\star}$ \\
$\operatorname{lipc}_{\mathrm{t}}$ & $2.306^{\star}$ \\
$\operatorname{linv}_{\mathrm{t}}$ & $0.312^{\star}$
\end{tabular}

$\mathrm{R}^{2}=0.99$; Adjusted $\mathrm{R}^{2}=0.99$. a. $\left(^{*}\right)$ the coefficients are significant at the $1 \%$; $\left(^{* *}\right)$ the coefficients are significant at the $5 \%$; $\left.{ }^{* * *}\right)$ the coefficients are significant at the $10 \%$. 
Eichengreen and Leblang (2008)'s conclusion that the larger the size of the economy, the more it is self-sufficient or, what amounts to the same thing, the less it exchanges with the outside world. The increase in domestic gross domestic product reduces the rate of trade openness by acting on the denominator of the ratio. The richer the country, the less incentive it is to interact with the outside world. The gross domestic product of the main trading partner $\left(\operatorname{lgdpf}_{\mathrm{t}}\right)$, the general price level (lipc $c_{t}$ ) and the investment $\left(\right.$ linv $_{t}$ ) have positive effects (respectively $2.545 ; 2.306$ and 0.312 ) at the threshold of $1 \%$. This result shows that the resulting increase in imports is largely offset by the joint decline in exports.

From these results, it becomes possible to determine a minimum level of democracy beyond which democracy would have a positive influence on trade openness.

Indeed, the minimum threshold of democracy is obtained by applying the formula [5] on the estimates in Table 2. We obtain a minimum threshold of democracy ( demo $_{t}^{*}$ ) of 4.576 corresponding to a "hybrid" regime. This result shows that democracy initially has a negative impact on Gabon's trade openness until it reaches a minimum threshold of 4.576 beyond which it has a positive influence on openness. Thus, the shift from an authoritarian regime (3.76) to a "hybrid" regime (4.576) reduces the rate of trade openness. Democracy exposes the state (politicians and bureaucrats) to the influence of several protectionist lobbies, mostly made up of national companies. This "hybrid" democracy leaves more room for maneuver to the interests of the agents of the State who manipulate trade policy decisions in order to satisfy the protectionist lobbies, which are more effective in the early stages of democratization. Beyond the threshold, when the effects of catching-up have exhausted, the transition from the hybrid system to an imperfect or even complete democracy increases trade openness. State agents see their margin of discretion reduced by a more transparent electoral process, increased pluralism, increased civil liberties, improved political participation and the functioning of government. Trade policies are increasingly responding to domestic demand reflecting the preferences of the majority of (free-trade) agents who benefit from free trade.

\section{Conclusion}

In this article we studied the relation between trade openness and democracy in Gabon from a nonlinear model. After estimating the direct impact of democracy on trade openness by the non-linear least squares method (or NLS), we have determined an optimal threshold beyond which democracy has a positive effect impact on trade openness in Gabon. More precisely, the results highlight a convex relationship between these two variables. Democracy reduces trade openness at first, and then it increases when the country reaches a hybrid democracy threshold higher than 4.576. However, trade openness, in a context of imperfect competition, exposes the country to external shocks with repercussions on the internal macroeconomic equilibrium of the countries and the monetary union. It might therefore be interesting to study the effect of trade openness on growth, 
unemployment or inflation in a monetary union such as the Economic and Monetary Community of Central Africa (EMCCA), Composed of small economies open to the outside and whose trade with the countries of the European Union is oriented towards economic partnership agreements.

\section{References}

[1] Balding, C. (2011) A Re-Examination of the Relation between Democracy and International Trade: The Case of Africa. UNI-WIDER Working Paper, 59, 1-24.

[2] Mayer, W. (1984) Endogenous Tariff Formation. American Economic Review, 74, 970-998.

[3] Mansfield, E., Milner, H. and Rosendorff, B.P. (2000) Free to Trade: Democracies, Autocracies, and International Trade. American Political Science Review, 94, 305321. https://doi.org/10.2307/2586014

[4] Kubota, K. and Milner, H. (2005) Why the Move to Free Trade? Democracy and Trade Policy in the Developing Countries. International Organization, 59, 107-143.

[5] Yu, M. (2010) Trade, Democracy, and the Gravity Equation. Journal of Development Economics, 91, 289-300. https://doi.org/10.1016/j.jdeveco.2009.07.004

[6] Siroën, J.M. and Granger, C. (2001) Les démocraties sont-elles plus ouvertes à l'échange? Économie Internationale, 88, 59-76.

[7] Eichengreen, B. and Leblang, D. (2008) Democracy and Globalization. Economics and Politics, 20, 289-334. https://doi.org/10.1111/j.1468-0343.2007.00329.x

[8] Duc, C., Granger, C. and Siroën, J.-M. (2007) Commerce et préférences. Les effets d'une clause démocratique. Revue Économique, 58, 1055-1076. https://doi.org/10.3917/reco.585.1055

[9] Findlay, R. and Wellisz, S. (1982) Endogenous Tariffs, the Political Economy of Trade Restrictions, and Welfare. In: Bhagwati, J. and Srinivasan, T., Eds., Import Competition and Response, University of Chicago Press, Chicago.

[10] Mitra, D. (1999) Endogenous Lobby Formation and Endogenous Protection: A Long Run Model of Policy Determination. American Economic Review, 89, 11161134. https://doi.org/10.1257/aer.89.5.1116

[11] Abeliansky, A. and Krenz, A. (2015) Democracy and International Trade: Differential Effects from a Panel Quantile Regression Framework. Discussion Papers, Number 243, Center for European Governance and Economic Development Research.

[12] Hamilton, C. (2002) Globalisation and Democracy. CEPR Discussion Paper 3653.

[13] Niyongabo, G. (2008) Politiques d'ouverture commerciale et développement économique. Ph.D. Thesis, Université d'Auvergne-Clermont-Ferrand I.

[14] Naudet, D. (1994) Une analyse du degré d'ouverture international. Economie Internationale, 58, 53-81.

[15] Otrou, A.H (2007) Les déterminants du commerce extérieur des pays de l'Union Economique Monétaire Ouest Africains (UEMOA), Revue du CAMES-Nouvelle Série B, 9, 235-243. 
Submit or recommend next manuscript to SCIRP and we will provide best service for you:

Accepting pre-submission inquiries through Email, Facebook, LinkedIn, Twitter, etc. A wide selection of journals (inclusive of 9 subjects, more than 200 journals)

Providing 24-hour high-quality service

User-friendly online submission system

Fair and swift peer-review system

Efficient typesetting and proofreading procedure

Display of the result of downloads and visits, as well as the number of cited articles Maximum dissemination of your research work

Submit your manuscript at: http://papersubmission.scirp.org/

Or contact me@scirp.org 